\title{
ULUSLARIN REKABETÇİ AVANTAJI: ELMAS MODEL ÇERÇEVESİ VE TÜRK TURİZM SEKTÖRÜNÜN REKABET GÜCÜ ${ }^{1}$
}

Adnan ÖZDEMİR

Öz

İletişim, ulaşım ve bilgi teknolojilerindeki gelişmeler, işletmelerin uluslararası rekabetten bağımsız kalma imkanını sınırlandırmıştır. Ülkeler uluslararası piyasada endüstriyel bazda rekabet gücü avantajı elde edebilmek için farklı yöntemlere başvurmaktadırlar. Turizm sektörünün ulusal ve uluslararası ölçekteki önemi ve büyüme kapasitesi ulusların bu sektöre yönelik atılımlar yapmasını sağlamıştır. Turizm endüstrisinin gelişmekte olan ülkelerin ekonomisine sağladığı istihdam, döviz girdisi, milli gelir ve diş ticaretine olumlu yansımaları ayrıca önem arz etmektedir. Porter, tarafından geliştirilen Elmas Modeli, sektörel düzeyde ülkelerin rekabet gücünü ortaya koymak için geliştirilmiş bir modeldir. Elmas modelinin dört ana faktörü olan; faktör koşulları, talep koşulları, ilgili destekleyici endüstriler, kurumsal yapı ve strateji ve beraberinde Porter'ın dışsal olarak kabul ettiği Devlet ve Şans faktörlerinden oluşmaktadır. Bu çalışmanın amacı, Türkiye Turizm Endüstrisin uluslararası arenada rekabet gücü avantajlarının Porter'ın geliştirdiği Elmas Modeli ile ölçülmesidir.

Anahtar Kelimeler: Turizm, Elmas Modeli, Rekabet Üstünlüğü, Rekabet Gücü, Rekabet Teorisi 


\title{
Competitive Advantage of Nations: Diamond Model Framework and Competitiveness of Turkish Tourism Industry
}

\begin{abstract}
With the developments in communication, transportation and information technologies, enterprises have limited the opportunity to remain independent of international competition. Countries apply different methods in order to gain competitive advantage in the international market. The importance of the tourism industry on national and international scale and the capacity of growth ensured that the nations made the necessary steps towards this industry. The positive effects of the tourism industry on employment, foreign exchange inflow, national income and foreign trade are also important. The diamond model developed by Porter is a model developed to reveal the competitive power of countries at sectoral level. The four main factors of the Diamond model are factor conditions, demand conditions, related and supporting industries, firms strategy and rivalry, as well as State and Chance factors that Porter deems to be external. The aim of this study is to measure the competitive advantage of the Turkish tourism industry in the international arena with the Diamond model developed by Porter.
\end{abstract}

Keywords: Tourism, Diamond Model, Competitive Advantage, Competition Theory, Competitiveness 


\section{Giriș}

II. Dünya savaşı sonrasında Amerika Birleşik Devletlerin Marshall Planı çerçevesinde Avrupa ülkelerine yaptığı yardımlar sayesinde, Avrupa ülkelerinin ekonomik kalkınmaları başlanmıştır. Avrupa ülkelerinin ekonomik kalkınmalarının sağlanması, teknoloji ve ulaşım da yaşanan gelişmelerle birlikte turizm sektörü canlanmaya başlanmıștır. Ekonomik kalkınma ile birlikte ekonomik refahta yaşanan yükseliş beraberinde sosyo-kültürel değișimler, yașam kalitesi ve standardının artması, insanların daha sağlıklı ve uzun ömürlü olma istekleri gibi, ulaşım ve iletişimdeki teknolojik gelişmeler, konaklama sektörlerinin yaygınlaşması, pazarlama ve halkla ilişkiler faaliyetlerinin etkinliği ile beraber kitle turizminin ortaya çıkması, toplumlarda tatil düşüncesinin yaygınlaşması, teknoloji ve sonucunda kitle haberleşmesinin gelişimi ve sınır formalitelerinin azaltılması dünya turizm hareketlerinin hızlı gelişmesinin nedenleri olarak ifade edilebilir (Özer, 2012, s.1).

Turizm sektörü ulusal ve uluslararası milli gelir, istihdam, dış ticaret payının önemli bölümünü oluşturması ve büyüme kapasitesi ile dünyada en hızlı gelişen endüstrilerin başında yer almaktadır. Dünya Turizm Örgütü (UNWTO) verilerine göre, 1950'de uluslararası ziyaretçi sayısı 25 milyon iken bu rakam 2016 yılında 1 milyar 235 milyon kişiye ulaşmıştır. $\mathrm{Bu}$ bağlamda uluslararası turizm hareketleri \%4000 oranında muazzam bir gelişmenin göstergesi olarak ifade edilmektedir. Turizm endüstrisinin Türkiye Gayri Safi Milli Hasıla (GSMH) içindeki payı 1980'da \% 0,6 ve toplam ihracat oranına \%11,2 iken 2017 yılı itibariyle bu oran GSMH içindeki payı \% 3,1'e çıkmış ve toplam ihracat oranına \%16,7'ye yükselmiştir. Buna ek olarak, turizm endüstrisi Türkiye genelinde çalışan nüfusun yaklaşık \%8'ine tekabül eden 1,3 milyonu aşkın bir istihdam yaratmış bulunmaktadır ve dolaylı istihdam ile birlikte bu sayı 3 milyonu geçmektedir.

Porter, bir ülkenin belirli endüstrilerde uluslararası rekabet gücünü elde edebilmesini 10 gelişmiş ülke endüstrisi üzerine yaptığı 4-yıllık çalışması sonunda Elmas Modeli (Diamond Model) ile ülkelerin nasıl rekabet üstünlüğü sağladığını açıklamıştır. Elmas modeline göre, bir ülkenin rekabet gücü ülkenin içinde faaliyet gösteren endüstriler ile sağlanmaktadır. Elmas Modeline göre bir ülkenin ulusal rekabet gücü; faktör koşulları, talep koşulları, ilgili ve destekleyici sektörler ve firma stratejisi yapısı ve rekabet unsurların yalnız veya birbirleri ile ilişkili 
ve birbirleriyle karşılıklı bir etkileşim içerisinde olduğunun ve bunun sonucunda ulusların rekabet gücünün arttığını öngörmektedir. Porter Elmas Modelindeki 4 temel faktörün yanında iki ek değişken olarak, şans ve devlet faktörlerini eklemiş ve bu iki değişkenin diğer temel faktörler üzerinde etkili değişkenler olarak açıklamıştır. Porter, Elmas modelini oluşturan değişkenleri mal ve hizmet sektörlerine yönelik ayrı ayrı açıklamıștır. Turizm endüstrisinin hizmet sektörü içinde yer almasından dolayı elmas modelinin faktör açıklamaları hizmet sektörü esas alınarak yapılmıștır.

Bu çalışmada, Porter Elmas Modelinin rekabet gücü faktörleri Türk Turizm Endüstrisi açısından değerlendirilecektir. Elmas Modeline yönelik eleștiriler ayrıca ele alınmıștır.

\section{Dünya Genelinde Turizm Sektörünün Durumu}

Turizmin sektörü büyümeye elverişli muazzam yapısı ile dünyanın en hızlı büyüyen faaliyetlerinin başında gelmektedir. UNWTO'un raporuna göre, dünya genelinde uluslararası turist ziyaretçi sayısı 1950'lerde 25 milyon iken 1980 yılında 278 milyona, 2000 yılında 674 milyona ve 2016 itibariyle bu sayı 1,235 milyona ulaşmıştır. Aynı şekilde, 1950'lerde 2 milyar dolar olan turizm gelirleri, 1980 yllında 104, 2000 yılında 495 ve 2016 itibariyle bu rakam 1,220 milyar dolara çıkmıştır. 2016 yılı toplam turizm ihracatı 1,4 trilyon dolar ile dünya mal ve hizmeti ihracatının $\% 7$ 'sine tekabül etmektedir.

Dünya turizminde başı 616 milyon ziyaretçi ile ülkemizin de yer aldığı Avrupa Bölgesi çekmektedir. Avrupa'yı sırasıyla 308 milyon ziyaretçiyle Asya-Pasifik bölgesi ve 199 milyon ile Amerika bölgesi takip etmektedir. Afrika bölgesi 58 milyon ziyaretçiyle dördüncü bölge olurken Ortadoğu bölgesinin çektiği 54 milyon turist ziyaretçi ile en sonda yer almaktadır (UNWTO, 2016, s.2). 


\section{Tablo 1}

Bölgeler ve Dünya Turizminden Aldığı Paylar (milyon kişi)

\begin{tabular}{|l|l|l|l|l|l|l|l|}
\hline $\begin{array}{l}\text { UNWTO Bölge- } \\
\text { leri }\end{array}$ & 1990 & 1995 & 2000 & 2005 & 2010 & 2015 & 2016 \\
\hline Avrupa Bölgesi & 261.5 & 303.5 & 386.6 & 453.2 & 489.0 & 603.7 & 616.2 \\
\hline $\begin{array}{l}\text { Asya Pasifik Böl- } \\
\text { gesi }\end{array}$ & 55.9 & 82.1 & 110.4 & 154.1 & 208.1 & 284.0 & 308.4 \\
\hline Amerika Bölgesi & 92.8 & 108.9 & 128.2 & 133.3 & 150.1 & 192.7 & 199.3 \\
\hline Afrika Bölgesi & 14.8 & 18.7 & 26.2 & 34.8 & 50.4 & 53.4 & 57.8 \\
\hline Ortadoğu Bölgesi & 9.6 & 12.7 & 22.4 & 33.7 & 55.4 & 55.6 & 53.6 \\
\hline
\end{tabular}

Kaynak: Dünya Turizm Örgütü (UNWTO) verilerinden derlenmiştir.

UNWTO 2016 yılı verilerine göre, dünyada en fazla turizm gelirini 206 milyar dolar ile ABD elde etmektedir. ABD'yi turizm gelirleri açısından 60 milyar dolarla İspanya takip etmektedir. Tayland 50 ve Çin de 44,4 milyar dolarla üçüncü ve dördüncü sırayı paylaşmaktadırlar. Dünya turizminde en fazla turist çeken Fransa 42,5 milyar dolar ile beşinci sıraya gerilemiştir. İtalya'nın 40,2 milyar dolar turizm geliri ile 6'ıncı sırada yer alırken, sırasıyla İngiltere, Almanya, Hong Kong ve Avusturalya izlemektedir.

\section{Tablo 2}

Dünya Turizm Gelirlerine Sahip İlk On Ülke (milyar dolar)

\begin{tabular}{|l|l|l|}
\hline Siralama & $\mathbf{2 0 1 5}$ & $\mathbf{2 0 1 6}$ \\
\hline ABD & 205.4 & 205.9 \\
\hline İspanya & 56.5 & 60.3 \\
\hline Tayland & 44.9 & 49.9 \\
\hline Çin & 45.0 & 44.1 \\
\hline Fransa & 44.9 & 42.5 \\
\hline İtalya & 39.4 & 40.2 \\
\hline İngiltere & 45.5 & 39.6 \\
\hline Almanya & 36.9 & 37.4 \\
\hline Hong Kong (Çin) & 36.2 & 32.9 \\
\hline Avusturalya & 28.9 & 32.4 \\
\hline
\end{tabular}


Kaynak: Dünya Turizm Örgütü (UNWTO) verilerinden derlenmiştir.

\section{Türkiye Turizm Endüstrisinin Ekonomideki Yeri}

Dünyada turizm hareketleri hızla gelişme gösterirken, Türkiye de gerek ekonomik kalkınma stratejileri kapsamında gerekse de yerel ölçekte turizm sektöründe çok hızlı bir büyüme göstermiştir. Turizm sektörüne yönelik çeşitli yatırımlardaki artış, milli gelir içinde turizmin payının yükselişi, hizmet sektöründe öncelikli istihdam alanı haline dönüşmesi, ödemeler dengesine ve dış ticarete olumlu katkısı ve yabancı sermayeyi ülkeye çekmesi sektörün önemini açıkça göstermektedir (Dilber, 2007, s.209).

Gelişmekte olan ülkeler grubunda yer alan Türkiye'nin, sanayi ve tarım sektörlerindeki ihracat ile ülkeye gerekli döviz girdisini sağlaması kısa ve orta vadede gerçeklemesi zor bir ihtimal olarak önümüzde durmaktadır. Turizm endüstrisine yönelik geliştirilecek stratejik ekonomik politikalar ülkenin ihtiyacını karşılayacak gerekli döviz girdisini sağlayabileceği dünya turizmistatistiklerine göre mümkündür. Ülkenin turizm sektöründe sürdürülebilir rekabet avantajı sağlaması halinde ülkenin sadece dış ticaret açığına olumlu etki ile sınırlı kalmayıp, milli gelir, istihdam ve ülkenin tanıtımına yönelik önemli bir etki yaratacaktır. Türkiye'nin ödemeler dengesi tablosuna bakıldığında Hizmetler Sektörünün sürekli fazla verdiği görülmektedir. Türkiye Merkez Bankasının verilerine göre 2015 dış ödemeler bilançosunda Hizmet Sektörünün tüm alt sektörlerinin toplam payı 24.208 milyon dolar ve bunun 21.248 milyonu turizm sektörüne aittir. Turizm endüstrisinin, Türkiye'nin dış ticaret açığına kapatma da olumlu etkisi sunmaktadır.

Turistik aktiviteler için 2003-2017 yılları arasında ülkemize ziyaret eden turist sayısı ve elde edilen turizm gelirleri Tablo 3'de belirtilmiştir. Bu veriler ışı̆̆ında 2003 yılında itibaren ülkeye gelen turist sayısının ve gelirinin, 2015'de Rusya yaşana kriz dışında, düzenli bir artış gösterdiği görülmektedir. Ancak, 2014 ve sonraki yıllar esas alındığında ziyaretçi sayısının artışına rağmen turizm gelirlerinde ciddi düşüşlerin olduğu görülmektedir. Bunun belirli başlı nedenlerinden biri, ülke de yaşanan ekonomik sıkıntıların Türk Lirasının yabancı para birimlerine karşı değer kaybı ve son yıllarda sektör tarafında geliştirilen Her Şey Dahil sistemidir. Her-Şey-Dahil sistemi ile, turistlerin tüm ihtiyaçlarının otel içinde karşılanması sebebiyle otel dışına çıkma gereksinimi duymamaktadır. Buda, turistin otele verdiği ücret dışında herhangi bir harcama yapmamasına sebep olmaktadır. Ayrıca, dünyada en çok turist 
ziyaretçi ülke sıralamasında 41.617 ziyaretçi ile İtalya'dan sonra 6'ıncı sırada yer alan Türkiye, toplam turizm gelirleri alanında ise mevcut yerini koruyamamakta ve 10 'uncu siralamaya gerilemektedir.

\section{Tablo 3}

Turizm Gelirleri ve Turist Sayısı (bin dolar)

\begin{tabular}{|l|l|l|}
\hline Yll & Turizm Geliri & Ziyaretçi Sayısı \\
\hline $\mathbf{2 0 0 3}$ & 13.854 .866 & 16.302 .053 \\
\hline $\mathbf{2 0 0 5}$ & 20.322 .112 & 24.124 .501 \\
\hline $\mathbf{2 0 1 0}$ & 24.930 .997 & 33.027 .943 \\
\hline $\mathbf{2 0 1 1}$ & 28.115 .692 & 36.151 .328 \\
\hline $\mathbf{2 0 1 2}$ & 29.007 .003 & 36.463 .921 \\
\hline $\mathbf{2 0 1 3}$ & 32.310 .424 & 39.226 .226 \\
\hline $\mathbf{2 0 1 4}$ & 34.305 .904 & 41.415 .070 \\
\hline $\mathbf{2 0 1 5}$ & 31.464 .777 & 41.617 .530 \\
\hline $\mathbf{2 0 1 6}$ & 22.107 .440 & 31.365 .330 \\
\hline $\mathbf{2 0 1 7}$ & 26.283 .656 & 38.620 .346 \\
\hline
\end{tabular}

Kaynak: TURSAB verilerinden derlenmiștir.

Türk Turizm Sektörünün, ülkenin GSMH içindeki payı (Tablo 4) incelendiğinde 1980 'da \%0,6 olan oranın 1995 'te \%2,9'a yükselmiștir. 1995 ile 2000 yılına kadar olan dönemde duraksadığı ve 2005 yılında bu oranın \%4,2'e yükselmiş ve 2010 yılında bu oranın 3,4'e düştügü görülmektedir. Turizm sektörünün toplam gelirlerin 2015 yılında \%6,2'e çıkarak en yüksek oranı görmüştür. 2015 yılında Rusya yaşanan kriz sonucunda 2016 yılında ciddi bir düşüş yaşanması beraber 2017 tekrar yükselişe geçmiştir. Turizm sektörünün ihracat içindeki payına bakıldığında GSMH'yle aynı düzende ilerlediği görülmektedir. 


\section{Tablo 4}

Turizm Gelirlerin GSMH ve İhracatına Oranları

\begin{tabular}{|l|l|l|}
\hline Ylllar & $\begin{array}{l}\text { Turizm Gelirlerin } \\
\text { GSMH'ye Oranı }\end{array}$ & $\begin{array}{l}\text { Turizm Gelirlerin } \\
\text { İhracata Oranı }\end{array}$ \\
\hline 1980 & 0,6 & 11,2 \\
\hline 1990 & 2,1 & 24,9 \\
\hline 1995 & 2,9 & 22,9 \\
\hline 2000 & 2,9 & 27,5 \\
\hline 2005 & 4,2 & 24,7 \\
\hline 2010 & 3,4 & 18,3 \\
\hline 2015 & 6,2 & 21,9 \\
\hline 2016 & 2,6 & 15,5 \\
\hline 2017 & 3,1 & 16,7 \\
\hline
\end{tabular}

Kaynak: TURSAB verilerinden derlenmiştir.

Türkiye'nin en çok yüzleşmek zorunda kaldığı problemlerinin başında işsizlikgelmektedir. Gelişmekte olan ülke konumunda bulunan Türkiye'nin sanayi ve tarım sektörlerinde yeteri miktarda istihdam sağlayamamışı işsizlik oranını artırmaktadır. Turizm endüstrisinin teknolojik gelişmelere rağmen, doğası gereği sürekli hizmet zorunluluğunun olması, emek-yoğun bir yapıda faaliyet göstermesinden kaynaklı, sektörün gelişimi ile beraber istihdam edecek kişi sayısı artmaktadır. Dolayısıyla ülkede turizm sektöründe yaşanan olumlu gelişmeler işsizlik problemini pozitif yönde etkileyecektir. Ülkemizin turizm endüstrisinde ki rekabet gücünün artması işsizliğin azalmasına yol açmaktadır. Nitekim tablo 5.'de görüldügü üzere, ülke turizm sektörünün gelişim ile birlikte eşzamanlı sektörün toplam istihdam oranı içindeki payı artmaktadır. 1990 yılından beri, 2010 ve 2012 yıllarındaki az sayıdaki düșüşler haricinde, turizm sektörünün ülkenin istihdamı katkısı istikrarlı bir șekilde artmıștır. Turizm sektörünün 2015 yllında ülkedeki toplam istihdamın içindeki payı \%8,3, yani ülkenin tümünde çalışan isçiler her 12'inden 1'i turizm sektöründe istihdam edilmektedir. 


\section{Tablo 5}

Turizm Sektöründe İstihdam (bin)

\begin{tabular}{|l|l|l|l|}
\hline Yıllar & $\begin{array}{l}\text { Doğrudan } \\
\text { İstihdam }\end{array}$ & $\begin{array}{l}\text { Doğrudan ve Dolaylı } \\
\text { İstihdam }\end{array}$ & $\begin{array}{l}\text { Toplam İstihdam } \\
\text { İçindeki Payı \% }\end{array}$ \\
\hline 1990 & 283 & 1.244 & 6.9 \\
\hline 2000 & 531 & 1.535 & 7.3 \\
\hline 2005 & 473 & 1.732 & 8.8 \\
\hline 2010 & 466 & 1.700 & 7.8 \\
\hline 2011 & 506 & 1.990 & 8.6 \\
\hline 2012 & 530 & 1.949 & 8.0 \\
\hline 2013 & 548 & 2.049 & 8.1 \\
\hline 2014 & 579 & 2.130 & 8.2 \\
\hline 2015 & 600 & 2.192 & 8.3 \\
\hline
\end{tabular}

Kaynak: TÜIK, WTTC, Kültür ve Turizm Bakanlı̆̆ı verilerinden derlenmiştir.

\section{Elmas Modeli}

Neden bir ülke belli bir endüstride uluslararası başarı elde eder? (Porter, 1998, s. 71). Bu soruya cevap bulmak için 1990 yılında Michael Porter, farklı karakteristik özelliklere sahip ve öncü sektörlerin bulunduğu 10 önemli ticaret ülkesinde (ABD, Almanya, Japonya, Danimarka, İtalya, İsveç, İsviçre, Birleşik Krallık, Güney Kore ve Singapur) ve 100'den fazla örnek endüstri üzerinde 4 yıllık bir araștırma yapmıştır. Bazı ulusların neden diğerlerine göre belirli sektörlerde daha rekabetçidirler? Neden başarılı firmalar sürekli yenilik yeteneğine sahip ülkelerdedir? Neden bu firmalar gelişimlerini durak vermeden sürdürmekte ve rekabetçi avantajın daha sofistike kaynaklarını aramaktadırlar? Bu soruların cevapları ülkelerin sahip oldukları 4 temel faktörün bölünmez bir sistem olarak nasıl ilişkilendiği ve etkileşim içerisinde olduğunu açıklayan Elmas Modelinde yatmaktadır (Özer, 2012, s. 41).

Porter'ın Elmas Modeline göre bir ülkenin ulusal rekabet gücü; faktör koşulları, talep koşulları, ilgili ve destekleyici sektörler ve firma stratejisi yapısı ve rekabet unsurların yalnız veya birbirleri ile ilişkili ve birbirleriyle karşıllklı bir etkileşim içerisinde olduğunun ve bunun sonucunda ulusların rekabet gücünün arttığını öngörmektedir. Porter 
Elmas Modelindeki 4 temel faktörün yanında iki ek değişken olarak, şans ve devlet faktörlerini eklemiş ve bu iki değişkenin diğer temel faktörler üzerinde etkili değişkenler olarak açılklamıştır.

Uluslararası arenada öncü olan endüstrileri ve bu endüstrileri olușturan firmaların stratejilerini inceleyen Porter, söz konusu firmaların değişmez tek ortak yönlerinin "yenilik yapabilme ve kalite yükseltebilme yeteneği (Porter, 1998, s. 27)" olduğu sonucuna varmıştır. Rekabetçi avantaj elde etmeyi sağlayan bu yeteneği sürdürmek, sahip olabilmek kadar önemlidir; bu da ancak sürekli gelişim ve iyileştirme ile mümkün olabilir çünkü hemen her yenilik başkaları tarafından kolaylıkla kopya edilebilmektedir. Porter, rekabetçi avantaja sahip endüstrilerin ve firmaların sahip olduğu bu yeteneklerin kaynağını ise "Elmas Modeli" adını verdiği ve Şekil-2' de gösterilen ulusun dört temel özelliğine bağlamaktır.

\section{Şekil 1}

\section{Porter'ın Elmas Modeli}

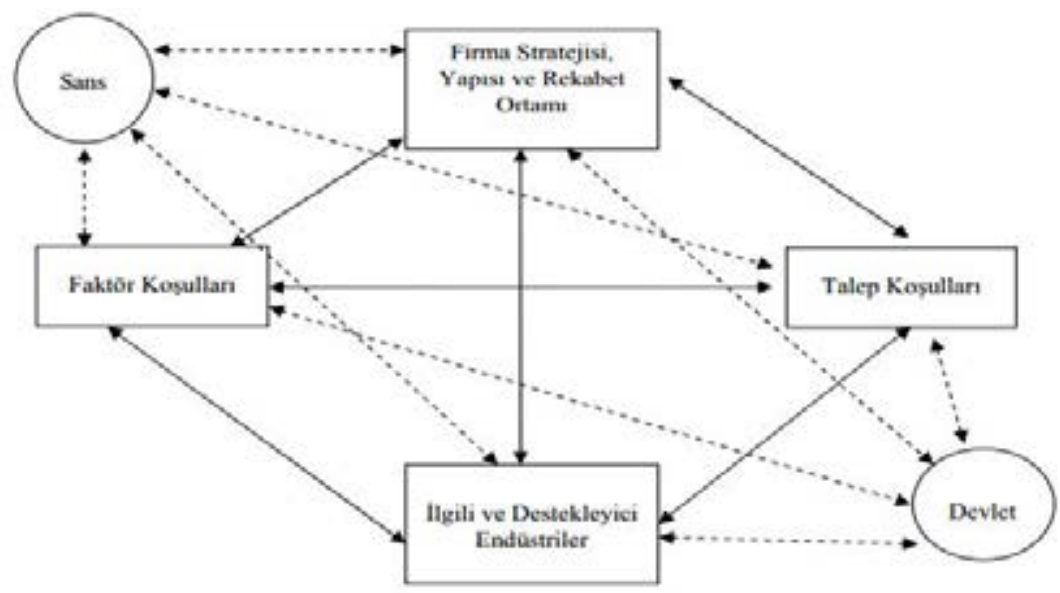

Kaynak: Porter, 1998, s.127

\section{Faktör Koşulları}

Bir ülkenin, uluslararası ticarette rekabet avantajına sahip olması için, o ülkenin sahip olduğu faktör şartlarına göre uygun ekonomik kalkınma planını gerçekleştirmesinden geçmektedir. Porter söz konusu faktör koşullarını belli kategoriler üzerinden incelemektedir bu faktörler şu şekilde sınıflandırılarak açıklanmaktadır (Porter, 1998, ss. 74-75);

- İnsan Kaynaklar; İşgücü nicelik ve niteliği, maliyetleri ve iş ahlakının 
düzeyi ile ifade edilmektedir.

- Fiziksel Kaynaklar; Ülkedeki arazi, su, mineraller, iklim, hammadde, enerji gücü kaynaklarının durumu, miktarı, maliyeti ve kalitesi ile ifade edilmektedir.

- Bilgi Kaynakları; Ülkelerin mal ve hizmetlere ilişkin pazar, bilimsel ve teknik bilgisi, araştırma ve istatistik enstitülerinin ve üniversitelerin varlığı ile ifade edilmektedir.

- Sermaye Kaynakları; Finansal sermayenin miktar ve maliyetleri ile tanımlanmaktadır. Ülkelerin güvende olan ve olmayan borçları, tahvil ve hisse senetleri, risk sermayesi kullanımı şeklinde farklı biçimlerde olabilir.

- Altyapı; Taşıma sistemleri, iletişim ve haberleşme ağı ile fon aktarım kolaylıkları, sağlık hizmetleri ve benzeri unsurlar olmakla birlikte aynı zamanda ülkeyi yatırım için cazip kılan niteliklerdir.

Porter'ın temel aldığı faktör kategorileri her farklı sektörün ihtiyacına göre farklılıklar gösterebilmektedir. Her ne kadar bu faktörlerin rekabet avantajı sağlaması açısından önkoşul olarak görülse de, miktar ve belirli bir endüstride derecesini vurgulamak nispeten önemsizdir. Bir ulusun rekabet avantajı sağlaması sahip olduğu faktör şartlarını düşük-maliyet, yüksek-kalite, verimlilik ve etkin kullanmasıyla paralellik göstermektedir.

Porter, çalışmasında faktör koşullarını, temel faktörler ve gelişmiş faktörler olarak ikiye ayırmıştır. Temel faktörler basit teknolojiye dayanan ve tarım ya da geleneksel sektörlerde kullanılırken, gelişmiş faktörler ileri teknolojiye dayanan ve kalifiye işgücü, modern altyapı, üniversite araștırma enstitülerini gibi unsurları kapsamaktadır. Bu bağlamda rekabet avantajı yaratmada temel faktörler yerine gelişmiş faktörlerin kullanılması önem taşımaktadır (Arslan ve Şahin, 2016, s. 4).

Hizmet sektöründe, ülkelerin sahip olduğu faktör donanımı belirli sektörde sahip olduğu rekabet avantajı ile direkt ilişkilendirilmektedir. Örneğin, turizm ağırlıklı olarak iklim ve coğrafyaya bağlıdır. Sıcak iklim şartları ve deniz kıyısına sınırı olan ülkeler coğrafi konumlarından dolayı turizm sektöründe diğer ülkelere göre daha avantajlı bir konuma sahip olmaktadırlar. Aynı şekilde, eğitim ve sağlık hizmetleri kalifiyeli eleman ve beceriye bağlıdır. Ülkelerin bulunduğu coğrafi bölge belirli bazı hizmet endüstrilerinde önemli rol oynamaktadır. Singapur'un gemi onarımındaki rekabet gücü, bulunduğu konumun Ortadoğu ülkeleri ile 
Japonya'yı birbirine bağlayan önemli deniz yolu üzerinde olmasından kaynaklanmaktadır (Porter, 1998, s. 256). Benzer şekilde, Türkiye'nin, Avrupa ile Asya'yı birbirine bağlayan coğrafi konumu lojistik sektöründe avantaj sağlamasına vesile olmuştur.

Porter'a göre, ulusların konuştuğu dil ve farklı dillere olan yatkınlıkları birçok hizmet sektöründe önemli bir rol oynayabilmektedir. Hizmet sektörün doğası gereği yoğun bir iletişim gerektirmekle beraber aynı firmanın ofisleri arasındaki iletişim ihtiyacı ayrıca önem arz etmektedir. Anadili İngilizce olan ülkeler hizmet sektöründe önemli bir avantaj elde etmektedirler çünkü İngilizce dünyanın çoğu yerinde konuşulmakta ve diğer tüm yerlerde de ikinci dil olarak öğretilmektedir. Günümüzde hizmet sektörlerinde öncü uluslararası firmaların çoğu İngilizcenin anadil ya da çoğunlukta konuşulduğu ülkelerden olması dilin önemini ortaya koymaktadır. Ayrıca, ulusların farklı kültürlerle olan etkileşim derecesi hizmet sektöründe önem arz etmektedir. Uluslararası rekabette öncü olan hizmet sektörü işletmelerin birçoğunun kültürel farklılıklara aşina olan uluslardan geliyor olması bunun en somut kaynağıdır.

\section{Talep Koşulları}

Talep koşulları, sunulan hizmetlere olan talep şekil ve çeşitliliğini ifade etmektedir. Talep koşulları, günümüz hizmet endüstrisinin uluslararası rekabet gücü açısından en güçlü tek belirleyicisi konumundadır. Küreselleşmenin ve ulaşım teknolojilerindeki gelişmelerden dolayı hizmet sektörü hızlı bir büyüme ve ilerleme dönemindedir. Pek çok yeni hizmet sektörleri ortaya çıkmakta ve mevcut hizmet sektörleri yeniden yapılandırılmaktadırlar. Talep koşulları bu sürecin ana yönlendirici faktörü durumundadır (Porter, 1998, s. 258). İç piyasadaki tüketicilerin talep kar olmaları uluslararası ticaret yönünden destekleyici bir unsurdur. Bilinçli ve nitelikli iç müşteri talepleri uluslararası piyasaya açılmakta olan ülke firmalarına rekabet avantajı olușturmaktadır. Porter, özellikle iç talebin gelecekte oluşacak talep yapısı hakkında firmalara doğru sinyaller verebilmesi halinde ulusların veya ulusal firmaların bu sinyali yabancı şirketlerden önce algılayarak rekabet avantajı sağlayacaklarını belirtmektedir (Bulu vd., 2006, s. 25).

Talep kompozisyonu: Bir ürüne iç pazardaki talep, dışarıdaki pazarlardaki talepten daha yüksek olduğu zamanlarda, yerel firmalar bu ürüne daha önem çok vermeleriyle beraber uluslararası piyasada rekabet avantajını elde etmektedirler (Porter, 1998, s. 259). Çoğu hizmet sektör firmaları, tüketicilerin bulunduğu yerlerde ofis veya şube açmak 
mecburiyetindedirler. Nüfusunun çoğunun birden fazla bölgedetoplanmış ülkelerin hizmet sektöründe faaliyet gösteren yerel firmaların birden fazla ofis ve şube açmasını gerektirmektedir. Yerel tüketici ihtiyaçlarını birden fazla şube veya ofis ile gideren yerel firmalar edindikleri tecrübeyle uluslararası piyasada rekabet avantajı elde etmektedirler. Birden fazla yurt içi ofise sahip olan yerel firmalar uluslararasılaşmada yerelde sahip oldukları kontrol mekanizmasıyla yurtdışında çok daha rahat ve kontrollü hareket etme kabiliyetine sahip olmaktadırlar. Otel zinciri, araç kiralama, finansal danışmanlık v.b. çoğu hizmet sektöründe Amerikan firmalarının rekabet avantajı kendi iç piyasalarda edindikleri tecrübeden kaynaklanmaktadır. Benzer șekilde, yerel tüketici kitlesinin bilinçli talep niteliği yerel işletmelerin uluslararası rekabet gücüne pozitif etki etmektedir.

Talep büyüklügü ve ilerleme düzeyi: Yurtiçi talebin büyük olması ülke firmalarının büyük ölçekli faaliyetlere, teknoloji geliştirmeye değişmeye verimliliği artırmaya yönelik alanlarda yatırım yapmaya teşvik eder (Porter, 1998, s. 93). Yerel pazarda herhangi bir hizmet sektörüne yönelik oluşan yüksek talep, yerel firmanın kalite ve verimliliğini artırmaya yönelik değişimlere sebep olmakla beraber uluslararasılaşma sürecinde işletmelere rekabet avantajı sağlamaktadır.

Hizmet sektöründe bilinçli tüketicilere sahip ülkelerdeki erken iç talep yerel firmaların uluslararası piyasada daha etkin rol oynamalarını sağlamaktadır. Örneğin, ABD'nin çoğu hizmet sektöründe, fastfood, hastane yönetimi, özel sağlık hizmetleri, danışmanlık hizmetleri gibi, uluslararası piyasada öncü olmasının temel nedeni tüketici kitlesinin bilinçli ve talep kar olmasından kaynaklı bu sektörlerdeki erken iç talebi fark edip yoğunlaşmalarından kaynaklanmaktadır.

Yurtiçi talebin uluslararasılaşması: Yoğun talepten kaynaklanan yerel talebin uluslararasılaşmada avantajlı hale gelebilmesi için yerel firmanın uluslararası piyasadaki hareketlenmeleri takip etme konusunda tetiklemektedir. Nüfusunun önemli oranı sık sık diğer ülkelere seyahat eden ülkelerin vatandaşları, kendi ulusların hizmet firmalarına ciddi rekabet avantajı sağlamaktadırlar. Yabancı ülkelere seyahat eden herhangi bir ülkenin vatandaşın önceliği bildiği, güvendiği ve aşina olduğu firmalar olmaktadır. Yerel firmaların diğer ülkelerde sadık bir tüketici kitlesine sahip olmaları, yerel firmaların hızlı bir şekilde uluslararası piyasaya güçlü bir şekilde açılmalarını sağlamaktadır (Porter, 1998, s. 262). Ulusların kendi kültür, standart ve uygulamalarını ihraç etmeleri yerel hizmet sektörüne uluslararası piyasada rekabet avantajı sağlamaktadır. 
ABD'nin uluslararası hizmet piyasasındaki gücü sık sık yurtdışı seyahatleri yapan vatandaşlarının etkisinden kaynaklanmaktadır. Örneğin, ABD'nin, özellikle de seyahatle ilgili sektörlerde, otel zincirleri, kredi kart firmaları ve araç kiralama şirketleri gibi, yurtdışında sahip olduğu sadık tüketici kitlesinden dolayı ciddi rekabet avantajı sağlamaktadır.

\section{İlgili ve Destekleyici Endüstriler}

Porter'a göre, ulusların rekabet üstünlügünü sağlayan üçüncü faktör ilgili ve destekleyici ama aynı zamanda rekabet gücü olan endüstrilerin varlığıdır. Yerel işletmelerin rekabet gücü içinde bulunduğu endüstrideki ilgili ve destekleyici işletmelerin varlığı ile paralellik göstermektedir. Uluslararası piyasada rekabet avantajına sahip sektörler kendi sektörleriyle ilişkili diğer sektörlere nazaran uluslararası rekabet avantajı sağlayabilmektedir.

$\mathrm{Bu}$ rekabet avantajı birkaç yolla olabilmektedir. Birincisi, rekabet gücü yüksek tedarikçiler maliyet etkin girdileri, hızlı, zamanında, verimli ve tercih edilen biçimde sağlayabilmektedir. Bir ülkede rekabet avantajına sahip sektörlerin varlığının yeni rekabetçi sektörlere öncülük ettiği ve avantaj sağladığı ifade edilmektedir. Bu durumda bir destek sektörün varlığı ilgili diğer sektör ve içerisinde faaliyet gösteren firmalara etkinlik, yenilikleri ilk uygulayan olma ve maliyet avantajı gibi önemli üstünlükler sunmaktadır. Özellikle sahip olunan etkin bir haberleşme ağı bu sektörler faaliyetlerini gerçekleștirme konusunda hız sağlayacaktır (Porter, 1998, ss. 104-106).

İkincisi, ilgili ve destekleyici endüstrilerdeki yenilikçi (innovation) ve gelişme faaliyetleri, destekledikleri endüstrilere rekabet gücü kazandırmaktadır. Ar-Ge'ye(araştırma ve geliştirme) yönelik ciddi yatırım yapan ilgili ve destekleyici endüstrilerin varlığı hizmet sektöründe faaliyet gösteren yerel firmalara rekabet gücü sağlamaktadır. İsviçre'nin ilaç sektöründeki rekabetçi gücü boya sanayisinde geçmişte elde ettiği uluslararası başarı ile ilgiliyken, Japonya fotokopi makinası üretiminde uluslararası başarıya elektronikle ilgili sahip olduğu diğer güçlü sektörlerin yardımı ile rekabetçi avantaj elde etmiştir (Porter, 1998, s.101). Benzer şekilde, rekabet gücü yüksek bilgisayar yazılım ve bilgi teknolojileri firmalarına ev sahipliği yapan Amerika'nın, hizmet sektöründeki faaliyet gösteren kendi ülke firmalarına bilgi işlem teknolojisi desteğiyle girdi maliyetlerinin azaltılması ve operasyon süreçlerini iyileştirilmeleri yönünden rekabet gücü sağlamaktadır. 


\section{Firma Stratejileri, Yapı ve Rekabet}

Porter’a göre uluslararası rekabet üstünlügü sağlayan dördüncü faktör, firma faaliyetinin gerçekleştirildiği sektörün yapısal özellikleri ile yerel rekabet durumu ve buna uygun olarak firmanın belirleyeceği stratejiye bağlıdır.

Evrensel olarak uygun kabul edilen ve rekabet gücünü temin edecek tek bir idare biçimi bulunmamaktadır. Rekabet gücü elde edebilmek için önemli olan, ülkede kabul gören yönetim ve organizasyon biçimleri ile sektördeki rekabet avantajı unsurlarını bütünleştirmektir. Örneğin İtalyan şirketlerinin dünya lideri olduğu sektörlere bakıldığında (ışıklandırma, mobilya, ayakkabı, kumaş ve paketleme makineleri gibi), daha odaklanmış, kişiye özel, hızlı değişim ve esneklik gerektiren şirket stratejilerinin, bu sektörlerin dinamik yapısı ve aynı zamanda İtalyan yönetim alışkanlıklarıyla uyumlu olduğu görülmektedir. Buna karşın, Almanya'daki şirket idare sistemi, hassasiyet ve yüksek idari disiplin gerektiren üretim yapısındaki teknik ve mühendislik odaklı sanayi biçimi ile uyumludur (Uzunkaya, 2013, s. 16).

Uluslararası rekabet avantajı sağlayan diğer önemli faktör iç piyasadaki rekabetin oranıdır. Bir ülke içindeki yerel işletmeler arasındaki rekabetin şiddeti işletmelerin yenilik ve gelişmeye yönelik zorlamaktadır. Yerel rekabetin yoğun ve güçlü olduğu ülkelerde, firmalar mevcut rekabet avantajlarını koruyabilmek için farklı alternatiflere yönlenmektedirler. $\mathrm{Bu}$ alternatifler, yeni inovasyon teknikleri, düşük fiyat, daha kaliteli ve verimli hizmetler, yeni ürünler veya hizmet sunuş biçimleridir. Güçlü yerel rekabet şartlarından dolayı şirketlerin uluslararasılaşmaları hızlandırmakla beraber rekabet güçlerinin daha da pekişmesine katkı sağlayabilmektedir.

Porter, yerel rekabetin olumlu etkileri, kümelenme(cluster) ${ }^{3}$ yani coğrafi yoğunlaşma ile arttığını, çünkü sektör üretimi veya hizmeti belirli bir coğrafi alanda yoğunlaştıkça rekabet de yoğunlaşmakta, dolayısıyla yerel rekabet etkisi güçlenmektedir. Belirli bir coğrafi bölgede yoğunlaşan firmaların tedarikçilerle aynı veya yakın bölgede yer alıyor olması, firmalara maliyet avantajı ve yeni teknolojilere daha hızlı ulaşmasına etki ettiğinden kümelenmelerin rekabet gücü üzerinde pozitif bir etki yaratmaktadır.

3 Benzer iş kolunda faaliyet gösteren, aralarında ilişkiler olan ama aynı zamanda rekabet de bulunan çok sayıdaki işletmenin, onlara mal satan tedarikçilerin ve hizmet satanların, ilgili kurumların (üniversiteler, meslek kuruluşları, iş koluyla ilgili standartları belirleyen ve kontrol eden kurumlar, vb.) aynı coğrafi bölgede yoğunlaşmalarıdır. 


\section{Şans Faktörü}

Uluslararası piyasada bugüne dek uluslararası rekabet gücüne sahip firmaların başarılı veya başarısız olmalarında şans faktörü rolü de olabilmektedir. Herhangi bir ülkedeki işletmeler kontrolü dışında gelişen olaylar işletmelerin rekabet gücüne olumsuz etkiler veya yeni firsatlar sunabilmektedir.

Örneğin, OPEC'in (Petrol İhraç Eden Ülkeler Örgütü) 1970'li yıllarda petrol fiyatlarında tekelleşmeye gitmesiyle elde ettikleri gelirleri altyapı yatırımlarına yönlendirmesi ve bu ülkelerin çoğunun din ve kültür olarak Türkiye'ye yakın olmaları neticesinde Türk inşaat sektörünün dışa açılım sürecine bu ülkelerde bașlaması bakımından bir șans faktörü olarak değerlendirilebilir. Aynı şekilde, 2010'lu yılların başından beri başlayan Libya'daki iç savaş ve Afrika ve Arap ülkelerin bir kısmında "Arap Baharı"4 olarak adlandırılan halk hareketlerinin ortaya çıkmasıyla ve ülke ekonomilerin istikrarsızlaşmasıyla Türk inşaat sektörünün uluslararası inşaat sektöründeki rekabet gücünü olumsuz etkilemektedir.

\section{Devletin Rolü}

Devlet'in modeldeki rolü, iç piyasada geliştirilmiş standartlar ile işletmeleri performanslarını yükseltmek için cesaretlendirmek, talep görecek ürünleri önceden tespit edip modellemek, özelleştirilmiş girdi üretimine odaklamak, bölgesel rekabeti engelleyecek doğrudan birliktelikleri (tekelleşme) kısıtlandırmaktır. Bu çerçevede, devletin rolünün Elmas Model'inin dört ana bileșenini destekler nitelikte olması gereklidir (Koç ve Özbozkurt, 2014, s. 89). Hükümetlerin yürürlüğe koyduğu kanun ve düzenlemeler bazı hizmetlere olan talebi doğrudan etkileyebilmekte ve yeni hizmet sektörleri ortaya çlkarabilmektedir. Yüksek çevre standartlarına sahip ülkelerde, temizleme, atık boşaltma ve benzeri hizmet sektörlerine olan yerel talep artmaktadır. Aynı şekilde, ulaşım sektöründe yüksek vergilerin varlığı araç kiralama ve leasing yöntemlerini olan talebi artırmaktadır.

Porter'e göre ulusal rekabetçiliğin arttırabilmesi için devletin, eğitim ile ilgili gelişmiş stajyerlik uygulamalarını ve sanayi-üniversite işbirliği ile yapılmış araștırma projelerini destekleyerek uzmanlaşmış işgücü

4 Birçok ülke, kuruluş ve alanda uzman kimseler, hareketlerin farklılığı ve sürekli sancılı, çalkantılı değișimi bahar olarak benimsemişlerdir ve bu halk hareketine Arap Baharı demişlerdir. 
oluşturmaya odaklanması gerekmektedir (Gökmenoğlu, vd. 2012, s.15). Hükümetlerin eğitim, bilim ve teknoloji politikaları ulusların rekabet gücüne direkt etki etmektedir. Nitekim günümüz dünyasına bakıldığında küresel pazarda öncü firmaların hemen hemen hepsinin gelişmiş ülkelerden çıkıyor olması bu ülkelerin nitelikli ve planlı eğitim, bilim ve teknolojik politikalarının etkisi görülmektedir.

\section{Elmas Modeli İle İlgili Eleştiriler}

Porter'ın 1990'da yayınladığı, “Ulusların Rekabet Üstünlügü̈” adlı eserinde ortaya koyduğu ve ulusal rekabet gücünü belirlemek için geliştirdiği Elmas Modeli ile akademik dünyada olumlu ve olumsuz yeni tartışmalara yol açmıştır. Elmas modelinin uygulanabilirliği, ampirik çalışmadan yoksun olması ve rekabetçi endüstrilerin belirlenmesinde kullanılan faktörlere yönelik ciddi eleştiriler dile getirilmiştir.

Porter'ın geliştirdiği elmas modeli ile farklı ülkelerdeki farklı endüstrilerin neden diğer ülke endüstrilerine göre daha rekabetçi olduklarını açıklamak üzere geliştirmiştir. Porter, elmas modeli sonucunda ulaştığı bulgular ülke ekonomik verileri ve incelemeleri sonucunda ulaşılmıștır. Herhangi bir ampiriksel geçerlilik sınamasına başvurmaması modeli eleştirilere açık hale getirtmiştir. Porter'ın geliştirdiği elmas modeli ulusal rekabet gücünü açılamada önemli bir model olmakla beraber elmas modeline yönelik çeşitli eleştiriler getirilmiştir.

Porter, uluslararası rekabette başarılı olmanın temel şartının elmas modelinin bir endüstride dört faktörünün eşzamanlı olarak güçlü olması gerekliliğini savunmuştur. Elmas modelinin dört faktörünü güçlü bir şekilde bünyesinde bulunduran ülke endüstrilerin rekabet açısından en güçlü endüstriye sahip olmaları beklenmektedir. Amerika ve Hindistan ülkelerinin yazılım endüstrisindeki rekabet şartlarına bakıldığında Hintlilerin yazılım endüstrisinde rekabet gücü kazandıracak herhangi bir elmas faktörüne sahip olmadıkları görünmektedir. Güçlü ve sofistike yerel talepten yoksun, ilgili ve destekleyici endüstriler zayıf ve faktör şartları bakımından gelişmiș faktörlerden yoksun ama basit faktörlerden ucuz işgücü (Smit, 2010, s. 121) dışında herhangi bir faktör avantajına sahip olmamalarına rağmen uluslararası piyasada yazılım endüstrisinin adeta lideri konumundadırlar. Hindistan'ın yazılım sektöründeki uluslararası başarısını elmas modeli çerçevesinde bakıldığında modelin zayıflı̆̆ını açıkça ortaya koymaktadır.

Porter'a göre basit faktör koșullarına (doğal kaynaklar, kalifiye 
olmayan işgücü vb.) sahip ekonomilerin rekabet güçleri sürdürülebilir değildir ancak gelişmiş faktörler koşullarına (kalifiye işgücü, Ar-ge dayalı endüstriler, vb.) sahip ekonomilerin rekabet gücü sürdürebilir olmaktadır. Cooper (1991)'a göre ise, ülke ekonomiler sadece basit faktör koşullarına sahip olmakla gayet rahat şekilde sürdürülebilir ekonomiye sahip olabilmektedirler. Örneğin, Yeni Zelanda'nın coğrafi konumundan dolayı sahip olduğu güzel doğa manzaralarını iyi pazarlama stratejisiyle sınırsız sayıda turist ziyaretçi kazanabilir ve rahat bir yaşam sürdürebilmelerini sağlar. Benzer şekilde, Suudi Arabistan'ın sahip olduğu yüksek derecedeki petrol rezervleri sayesinde sürdürebilir rekabet avantajının sahip olduğunu belirtmektedir (Grant, 1991, s. 541). Bunların yanında, Cartwright (1993), Rugman and D'Cruz, (1993) ve Hodgetts (1993) ekonomistlerde basit faktörlere sahip ülkelerin rekabet avantajı sürdürebilir olduğu yönünde görüş belirtmişlerdir (Konsolas, 2002, s. 22).

Porter, uluslararası rekabeti etkileyen farklı talep koşullarını rekabet gücü üzerinde önemli etkileri olduğunu belirtmiştir. Ülke içindeki yerel talep boyutunun ve çeşitliliğinin rekabet gücüne olumlu etki edeceğini belirten Porter'a, bazı ekonomistler karşı çıkmıștır. Yerel talebin boyutunun uluslararası rekabet gücüne etkisi ile ilgili çeşitli argümanlar ortaya atılmıştır. İlk argümana göre, iç talebin yüksek olduğu yerel pazarda yerel firmalar ihracat veya dış piyasalara açılma yerine mevcut pazarlarına odaklanmayı tercih edebilirler. Öte yandan, iç talebin az olduğu ülkelerdeki yerel firmalar, uluslararası piyasalarda daha aktif olmak durumundadırlar. Diğer bir argümanda, yerel talebin yüksek olduğu pazarlarda, yerel firmalar mevcut pazarlarına odaklanarak ölçek ekonomilerden faydalanarak mevcut pozisyonunu sağlamlaștırma ve geliştirmeyi uluslararası piyasaya açılmaya tercih edebilmektedirler (Öz, 1999, s. 17).

Porter'ın devlet rolünü elmas modelinde dişsal bir faktör ve firmaların rekabet gücü üzerine etkilerini dolaylı olarak kabul etmiştir lakin devletin faktörünün rekabet gücü üzerinde direkt rolü olduğunu kabul etmemiştir. Stopford ile Strange ve Van den Bosch ile De Man, Porter'dan farklı olarak devlet faktörünün rekabet gücü üzerinde direkt etkisi olduğunu ileri sürmüşlerdir. Stopford ile Strange'e göre, elmas modelinin az gelişmiş ve gelişmekte olan ülkeler uygulanabilirliğinin "küçük ve fakir ülkelerin piyasa şartlarını mevcut firmaların belirlemesine izin verme lükslerinin olmadığı(Stopford ve Strange, 1991, s. 8)" ndan kaynaklı devlet rolünün beșinci faktör olarak baz alınmasının zorunlu olduğunu belirtmişlerdir. Benzer șekilde, Van den Bosch ile De Man (Bosch, 1994, s. 54), Porter'ın 
devlet rolünü endüstri üzerindeki rolünü makro düzeyde incelediğini ve devlet faktörünün endüstri üzerinde olumlu ve olumsuz etkilerinin zamanla yok olduğu tezine karşı çıkmışlardır ve devlet rolünün modelinin beșinci temel faktörü olması gerektiğini savunmuşlardır.

Elmas modeline yönelik diğer bir eleştiride, Van Den Bosch ve Van Prooijen tarafından dile getirilen ve Porter'ın modelinin ulusların rekabetçi avantajı üzerinde ulusal kültürün etkisine çok az değinildiğini ve önem verilmediğine yöneliktir. Bu iki akademisyene göre "elmas modelinin tüm faktörleri ulusal kültür üzerinden inşa edilmektedir" (Bosch ve Prooijen, 1992, s. 175).

\section{Türk Turizm Sektörünün Elmas Modeli Çerçevesinde Değerlendirilmesi}

\section{Faktör Koşulları}

Porter, faktör koşullarını kendi içinde temel ve gelişmiş faktörler olarak iki gruba ayırmaktadır. Temel faktörler, fiziksel yani doğada doğal olarak bulunan, ülkedeki arazi, su, mineraller, iklim, tarihsel ve kültürel ve doğal kaynaklarının köklerine sahip faktörlerdir. Gelişmiş faktörler ise, bilgi, altyapı ve sermaye kaynakları olarak adlandırılmıștır.

Turistlerin gözüyle değerlendirildiğinde, faktör koşulları, turisti o bölgeye veya hedefe iten fiziksel, tarihi, kültürel kaynaklardır. Yani, o bölgenin veya varış yerinin çekiciliği, turistin seyahat etme kararında en önemli faktördür. 0 ülkede zaten var olan bu kaynaklar, çaba harcamaya gerek kalmadan bölgenin veya istenen hedefin rekabet gücü üzerinde doğrudan etki yaratan unsurlardır(Esen ve Uyar, 2012, s. 624).

Türkiye'nin coğrafi konumundan kaynaklı sahip olduğu iklim şartları turizm endüstrisinin başlıca temel faktör avantajıdır. Ülkenin, Akdeniz ve Ege Bölgesinde hakim olan llıman Akdeniz iklimi sayesinde bu bölgelerde nispeten kısa kışlar ile uzun ve güneşli yaz günleri etkisini göstermektedir. Bu da özellikle 6 aydan fazla süren yaz aylarının "deniz, kum, güneş" isteyen turistler için cazip hale getirmektedir. Türkiye'nin diğer tarafında yer alan Karadeniz ve Doğu Anadolu bölgelerinde hakim olan Karadeniz ve Karasal iklim sayesinde kış turizmi için popüler bir destinasyon olarak görülmektedir. Ülkenin sahip olduğu doğal kaynaklar uzun güneşli gün sayısı, uzun sahil kıyı şeritleri ve birbirinden farklı turizm rekreasyon kaynaklarına elverişli akarsu, göl ve kayak sporuna müsait dağlık bölgeleri faktör koşulları için önemli bir yön olarak kabul edilmektedir. 
Türkiye'nin, tarih boyunca farklı medeniyetlere ev sahipliği yapmış olması diğer önemli bir temel faktör avantajına sahip olmasını sağlamıștır. Bilinen tarihin ilk günlerinden kalma șehir, anıt, mağara, vb. yüzlerce kültürel mirasa ev sahipliği yapmaktadır. UNESCO'nun Dünya Kültürel ve Doğal Mirası Listesinde 2018 yılı itibariyle tüm dünyada 1092 miras yer almaktadır. Türkiye'nin söz konusu listede toplam da 18 miras alanı bulunmaktadır. Türkiye'deki bölgeler arası gelişmişlik ve farklı etnik kökene sahip millet çeşitliliği farklılıklarından kaynaklı, ülkenin her bir bölgesinde o bölgeye özgü birçok farklı gelenek ve göreneklerin ortaya çıkmasına sebep olmuştur. Küreselleşme, göç ve teknolojinin etkisiyle kaybolmaya yüz tutmaya başlanan bu gelenek ve görenekler, turizmin ilgisiyle beraber gelenek ve göreneklerin tekrar canlanmasına yol açmıştır. Bölgelere özgü özel geleneksel kıyafet ve yiyecekler, oyun ve merasimler bir bütün olarak kültür turizmin tamamlayıcı faktörleri arasında yer almaktadır.

Ülkenin derin geçmişinden dolayı sahip olduğu kültürel mirasların keşfedilmesinde yaşanan sıkıntılar, koruma ve tanıtımı açısından ortaya çıkan aksaklıklar turizm sektörüne yönelik olumsuz intibaya yol açmaktadır. Turizm talebin yüksek olduğu bölgelerde devlet ve özel kurumlar tarafından koruma altına alınıp işletmeye açılması ile beraber turizm talebinin az olduğu bölgelerde keşfedilmeye veya koruma altına alınmayı bekleyen bir sürü kültürel miras bulunmaktadır. Bu durum Türkiye açısından geliştirilmesi gerekli zayıf bir yön olarak tespit edilmiștir.

Türkiye'nin kara sınır komşuları olan İran, Suriye, Irak, Ermenistan, Gürcistan, Yunanistan ve Bulgaristan'ın dünyanın turizm gelir istatistiklerine göre sadece küçük bir bölümünü uluşturan düşük gelirli ülkelerden olmaları ve bu ülkelerdeki savaş, ekonomik ve siyasi belirsizlikler ülke turizm rekabet gücü açısından olumsuz faktör koşulu yaratmaktadırlar. İran'da siyasi ve ekonomik belirsizlikler ile Suriye ve Irak'ta devam eden iç savaştan kaynaklı Türkiye'ye göç edenlerin sayısı gün gün artmakta ve bu göçler ülke turizmine ciddi zarar verebilmektedir.

Bilgi ve haberleşme kaynakları açısından ülkenin sahip olduğu, ulusal ve uluslararası gazete, dergi, televizyon kanallarının sayısı, fiber internet ağının gelişmişliği ve kolay ulaşılabilirliği ve farklı iletişim kaynaklarının çeşitliliği turizm endüstrinin güçlü yönleri olarak kabul edilmektedir. Ülkenin tümünde erişilebilir internet altyapısının varlığı, birden fazla sabit ve cep hat operatörlerinin faaliyet gösteriyor olmaları önemli bir faktör olarak kabul görmektedir. Turizm endüstrisindeki bilgi teknolojilerinin 
yazılımlarının yabancı kaynaklı olması turizm endüstrisinin bilgi teknolojileri açısından zayıflığını göstermektedir.

Turizm endüstrisi açısından gelişmiş ulaşım altyapısının varlığı güçlü bir yön olarak değerlendirilmiştir. Türkiye, özellikle 2000'li yıllardan sonra deniz, hava, ulaşım ve altyapı çalışmaları için önemli gelişmeler katletmiştir. T.C. Ulaştırma Bakanlığı verilerine göre, 2017 yılı itibariyle 67,620 km karayolu, 12,608 km demir ray sistemi ve 55 tane havalimanı ve hala yapım aşamasında olan ve Ekim 2018 yılında açılması planlanan 3. Havalimanı, dünyanın en büyük 10 havalimanından biri olacak, ciddi gelişmelere yol açacaktır. Özel havayolu şirketlerin kurulması, hızlı tren seferlerin başlanması, otoban ve duble(çift yönlü gidiş-geliş) karayolların yapılması gibi gelişmeler ülkenin turizm endüstrisine pozitif katkılar sunmaktadır.

Türkiye'de ağırlıklı olarak kitle turizm talebi ile karşı karşıya olan ve son yıllarda hızla yükselen turizm endüstrisi gerek asıl faaliyet alanı sanayi olan firmaların sıcak para akışı sağlama amacı gütmesi gerekse yap işlet devret modelinin inşaat firmaları tarafından ilgi çekici görülmesi ile yerli ve yabancı sermaye tarafından ilgi görmektedir (Özer vd., 2012, s. 1067) Yap-ișlet-devret modeli ile turizme yönelik yașanan sermaye akıșının önündeki engel kalkmış olmaktadır. Bu durum güçlü bir yön olarak ifade edilmiştir. Aynı zamanda, uluslararası piyasada marka haline gelmiş zincir otellerin ve seyahat firmalarının gerek direk gerekse de ortak girişimle ülkede yatırım yapmaları ülke turizmin uluslararası rekabet gücü için olumlu katkı sağlamaktadır. Ancak, uluslararası tur operatörlerinin ağırlıklı olarak yabancı sermaye elinde bulunması olumsuz bir etken olarak karşımıza çıkmaktadır. Tur operatörlerinin yabancı olması döviz girişinin dolaylı yollardan yurt dışına geri dönmesi ve yurt dışından gelecek olan turizm talebinde kaliteli talebin Türkiye'ye yöneliminde sürdürülebilirliği olumsuz etkilemektedir (Özer, 2012, ss. 89-90).

Nitelikli işgücüne sahip işletmeler, yüksek hizmet kalitesine sahip olmakla işletmeye gelen turistlerin sürekliliğini sağlamakta ve ülke rekabet gücüne olumlu katkılar sağlamaktadır. Türkiye'de eğitilmiş nitelikli işgücü açısından, turizm meslek liseleri ile üniversitelerin turizm eğitimi veren bölümlerinde eğitim almış yüksek rakamlardaki insan kaynağı her yıl mezun olmaktadır. Mezun olan öğrencilerin turizm endüstrisi için gereksinim duyulan nitelikli işgücü boşluğunu doldurmaktadır. Bu durum turizm rekabet gücü açısından güçlü bir yön olarak kabul edilmektedir. Ancak turizm tesislerinde ucuz ișgücüne yönelmeler, İngilizce eğitiminin yeterli düzeyde olmadı̆̆ı ve diğer yabancı dillerin (Rusça, Almanca, 
Japonca, İspanyolca vb.) pek fazla önem verilmemesi bu pazarlara yönelik bağlantılarında eksikliklere yol açmaktadır. Bu eksikler turizm rekabet edilebilirliği açısından zayıf bir yön olarak kabul edilmektedir.

Ülkenin sahip olduğu temel faktör koşulları, Türkiye'nin turizm endüstrisi için beraberinde çok önemli avantajlar getirmektedir. Ülkenin sahip olduğu doğal kaynaklar uzun güneşli gün sayısı, sahiller, arkeolojik ve kültürel cazibe merkezleri yanı sıra farklı turizm rekreasyon aktiviteleri açısından elverişli akarsu, göl ve kış sporlarına müsait iklim ve dağlık bölgeleri varlığı turizm endüstrisinin gelişimini etkileyen önemli faktörler arasındadır. Gelişmiş faktörlerden olan sermaye kaynakları ve ulaşım ve altyapının gelişmişliği ülkenin rekabet gücüne olumlu etki etmektedir. Diğer gelişmiş faktörler deki, nitelikli işgücü, kültürel mirasların korunma ve yönetimi, bilgi teknolojileri gibi, eksiklikler ülke turizmin rekabet gücüne olumsuz etki etmekle beraber bu eksikliklerin giderilmesi noktasında yapılan çalışmaların bitirilmesi ile beraber ülke turizm rekabet gücüne ek avantaj sağlayacaktır.

\section{Talep Koşulları}

Türkiye'deki turizm faaliyetlerine iç talebin yüksek olması uluslararası piyasada ülke turizminin rekabet gücünü pozitif yönde etkilemektedir. Türk turistler de, yabancı turistler gibi, "deniz kum güneş" kombinasyonun bulunduğu ılıman Akdeniz iklimine sahip yerleri tercih etmeleri sezon da doğan boşlukları doldurmaları talebi artırmaktadır.

Türkiye paket tur ve her şey dahil sistem dahilinde kitle turizm talebinin yoğun olduğu bir destinasyon olarak tanımlanmaktadır. Bu durum yüksek işlem hacmine sahip yurtiçi tur operatörleri tarafından olumlu görülse de her şey dahil konseptlerde deniz kum güneş standardından ziyade durumdaki iç bölgelere yönelik turizm hareketini zayıflatmakta ve turizm hareketinin ülke geneline yayılması açısından olumsuz bir durum ortaya çıkarmaktadır. Tur paketlerinin yaz aylarına odaklanmış olmasından dolayı deniz kum güneş turizmi ve Kapadokya gibi marka haline gelmiş birkaç turizm bölgesi dişında kalan diğer bölgeleri olumsuz etkileyen bir durum çıkmaktadır(Özer, 2012, s.101). Ülkenin tarihi geçmişe sahip, aynı zamanda turizm kentleri olan, İstanbul ve İzmir gibi şehirlerin sağlık ve sanayi gelişmişlikle beraber ülkeye sağladığı iş seyahatleri, kongre ve fuarlara yönelik turist talepleri de ülke turizm için güçlü bir yön olarak kabul edilmektedir.

Türk turizm endüstrisinin uluslararası arenada rekabet gücünü zayıflatan 
en önemli faktörlerin başında, ülkenin turizm faaliyetlerini kendi dil, kültür ve gelenekler yerine dış talebin beklentilerine göre şekillendirmesidir. Porter, elmas modelinde, ulusların kendi kültür, standartve uygulamalarını ihraç etmeleri yerel hizmet sektörüne uluslararası piyasada rekabet avantajı sağladığını belirtmiştir. Türkiye'de, özellikle sezonluk kitle turizm sektöründe bulunan işletmeler, Türkçe yerine yabancı dil kullanımı, geleneksel mutfak ve servis yerine yabancl mutfak ürünleri ve servis şekilleri, geleneksel müzik ve eğlence organizasyonları yerine yabancı müzik ve eğlence tarzları benimsenmiştir. Bu da ülkenin kendi kültürel ve geleneksel ürünlerinin tanıtılmasında ve bilinirliğinin artmasına ciddi bir engel olușturmaktadır. Yabancı turistlerin kendi kültür ve geleneklerine uygun hizmet görmesi ülke turizminin uluslararasılaşmasında zayıf bir yön olarak kabul edilmektedir.

\section{İlgili ve Destekleyici Endüstriler}

Turizm endüstrisinin genel yapısı itibariyle içerisinde yer alan firmalar birbirine iç içe geçmiş seyahat, konaklama, eğlence, yiyecek içecek sektörlerinin birbirleriyle hem tedarikçi ve alıcı rollerinde oldukları bir yapıda hem de model de yer alan bağlantılı endüstriler kapsamında birbirleriyle ilişki içinde bulunmaktadırlar (Özer vd., 2012, s. 1072). Türk turizm sektörünün sahip olduğu yiyecek ve içecek sektörünün uluslararası rekabet gücü turizm endüstrisine avantajlı hale getirtmiştir. Ülkedeki işletmelerin belirli lokasyonlarda kümelenmelerin ve yeterli sayıda tedarikçinin varlığı güçlü bir yön olarak tanımlanmıştır. Turizm işletmelerin tedarikçi konumunda bulunan inşaat, mobilya, gıda üretimi, tekstil ve iletişim sektörlerin sayıca çok olması ve turizm kümelenmelerin olduğu lokasyonlara yakınlığı, turizm işletmelerine maliyet avantajı sağlamaktadır.

Ar-Ge'ye(araştırma ve geliştirme) yönelik ciddi yatırım yapan ilgili ve destekleyici endüstrilerin varlığı hizmet sektöründe faaliyet gösteren yerel firmalara rekabet gücü sağlamaktadır. Turizm sektörünün yapısı gereği faaliyet gösteren işletmeler hem tedarikçi hem de rakip konumunda bulunmaktadırlar. Bu durum işletmeler arasında sürekli bir rekabete yol açmaktadır. Firmalar arasındaki rekabetin etkisiyle sürdürülebilir ve yenilik yapma eğiliminin yükselmesi sebebiyle tedarikçi firmaların gelişmişlik düzeyi ilerledikçe rekabet gücüne olumlu katkı yapmaktadır. Ayrıca, tekstil sektörü tarafından üretilen geleneksel ve modern kumaş ve giysiler ile geleneksel el sanat ürünleri ülke turizmin rekabet gücüne pozitif etki yaratmaktadır. 


\section{Kurumsal Yapı ve Strateji}

Küresel ölçekte turizm sektöründe, firmanın rekabet gücünü artırıcı etkiye sahip standart bir yönetim organizasyon biçimi yoktur. Ülkedeki turizm firmalarının genelinde, iç piyasa da kabul gören yönetim ve organizasyon biçimlerinin dış piyasa yönetim ve organizasyon şekillerinin rekabet avantajı unsurlarını bütünleştirici bir organizasyon biçiminde yürütülmektedir. Turizm sektöründe faaliyet gösteren yerli firmalar, işletme yönetim ve strateji becerilerini sektörel değişimleri temel alarak sürekli olarak yenilemektedirler. Uluslararası turizm sektörünün öncü firmaların yönetim tarzların kendi yönetim biçimlerine uygulayarak veya belirli derecede kendi organizasyon sistemlerine kopyalama yöntemi ile ekleyerek uluslararası rekabette avantaj elde etmektedirler. Bununla beraber, yerli turizm işletmelerinin teknolojik gelişmeler ve yenilikleri adapte etmekteki becerileri rekabet gücü açısından pozitif bir etki yaratmaktadır. Uluslararası turizm endüstrisinde ortaya çıkan yeni pazarlama, tanıtım veya rezervasyon yöntemlerinin uygulamaya alınması yerli turizm işletmelerinin küresel çapta rekabet edilebilirliğine olumlu katkı sağlamaktadır.

Turizm sektöründeki iç rekabetin seviyesi uluslararası arenada rekabet edilebilirliğin güçlü olmasına neden olmaktadır. Ülkenin turizm sektöründe faaliyet gösteren işletmeler arasında ki rekabet oranının yoğunluğu özellikle de kümelenmelerin olduğu bölgelerde çok yüksektir. Yerel işletmeler arasında rekabetten kaynakll, işletmeler, mevcut rekabet avantajlarını koruyabilmek içim farklı alternatifler geliştirmek zorunda kalmaktadırlar. Bu alternatifler firmanın yönetim bazlı, daha iyi ve kaliteli hizmetin daha ucuza sunulması veya farklı inovasyonlar geliştirmeleri gibi yenilikler olabileceği gibi, farklı yöntemlere de başvurulabilmektedirler. Ülkedeki turizm işletmelerinin, uluslararası piyasada bilinirliği olan veya lider konumunda olan zincir otellerle markalaşma yoluna gitmekte veya kendi yerli markasını yaratma yolunda adımlar atmaktadırlar. Türkiye'de uluslararası turizm sektörünün öncü tüm zincir otellerin, Hilton, Hyatt, Four Season vb. faaliyet gösteriyor olması, ülke turizm sektörüne rekabet gücü katmaktadır. Benzer şekilde, yerel işletmelerin markalaşmaya başlaması, Rixos, Divan, Titanic gibi, ve kendi markasıyla uluslararası piyasa açılması ülke turizmin uluslararası arenada rekabet gücünü artırmaktadır.

Yerel turizm endüstrisinin özel işletmeler tarafında serbest piyasa şartları altında hareket etmesiyle birlikte ulusal çapta kurulan kuruluş veya derneklerin rekabetçilik üzerine az da olsa olumsuz yönde 
etkileyebilmektedir. TÜRSAB, TÜROFED, TTYD, TÜROB, TUREB gibi kuruluşların biraz da devletin desteğiyle turizm sektöründeki rekabetçilik ortamına negatif etki etmektedir. Örneğin, dünyanın en büyük online rezervasyon sitesi olan booking.com'un yurt içi müşterilerine kapatılması, yerel rekabetin oranının düşmesine ve fiyatların artmasına sebep olmuștur.

\section{Devlet Faktörü}

1963 yılında Turizm ve Tanıtma Bakanlığının kurulmasıyla turizm sektörü resmi olarak hükümet tarafından desteklenmeye başlanılmıştır (kültür.gov.tr). Türkiye'de turizm sektörünü farklı devlet teşvikleri ile desteklenmeye çalışılmıştır. Hükümet tarafından yerel işletmelere yatırım teşvikleri destekleri ile beraber mevcut işletmelerin faaliyetlerinde de faiz, nitelikli işgücü ve vergi destekleri sunmaktadır. Örneğin, turizm sektöründe yüzde 18 olan K.D.V. oranlarını 2008 yılında yüzde 8 oranına düşürmüştür. Ülke ayrıca turizm sektörünü ulaşım imkanlarını geliştirilmesi bağlamında da ciddi yatırımlar gerçekleşmiştir. Turizm potansiyeli olan bölgelerde bulunan havaalanları sayısını artırmak, havayolu sektöründe markalaşmaya gitmek, mevcut yolların geliştirilmesi veya yeni duble yolların yapılması ve yabancı turizm firmaların ülkeye girişleri için kolaylaştırıcı önlemler almıştır. Bu tür devlet desteklerin sektöre uluslararası alanda rekabet gücüne olumlu yönde etkilemektedir.

Turizm sektörünün kırılgan yapısından dolayı, ulusal ve uluslararası ilişkilerde ülke ilgili gelişmeler sektöre ciddi zararlar verebilmektedir.24 Kasım 2015'de düşürülen Rus uçağı, ülkenin sahip olduğu en büyük turist kitlesi olan Rusların, Türkiye'ye gelmemelerine neden olmuştur. Türkiye ziyaret eden Rus turist sayısı 2015'te 3.649 bin iken uçak olayından sonra bu sayı 866 bine düşmüştür (TURSAB, 2017). Türkiye'nin diğer ülkelerle olan ilişkileri, turizm rekabet avantajı açısından, direkt olumlu veya olumsuz sonuçlar doğurmaktadır. Benzer şekilde, ülkede yaşanan veya yaşanabilecek terör olayları da turizm sektörü açısında negatif sonuçlara vesile olmaktadır.

\section{Şans Faktörü}

Türkiye turizm sektörü için şans faktörlerinin daha çok uluslararası piyasada rakip olanülkelerde yaşanan siyasi istikrarsızlıkve iç karışıklıktan dolayı talep kaymasının yaşanmasıdır. Şans faktöründen kaynaklı olaylar uluslararası arenada rekabet gücüne sahip uluslararası firmaların sahip olduğu avantajların kaybolmasına sebep olabilmekte ve ülkenin yerel 
firmaların uluslararası piyasada ortaya çıkan fırsatları değerlendirerek rekabet avantajı elde edebilmesine firsat tanıyabilmektedir. Bu tür talep kaymaları, ülke turizmine güç katmaktadır.

\section{Sonuç}

Türkiye, dünya turizm sektöründe en çok ziyaret çeken ilk 10 destinasyon arasında bulunmaktadır. Turizm sektörü ülke ekonomisine çok önemli olumlu katkılar sağlamaktadır. 2017 yılında, Türkiye ekonomisinin GSMH 'sının yüzde 3,1'ni turizm endüstrisi oluşturmuştur. Ülkenin dış ticaret açığına döviz girdisiyle destek sağlamakta ve ülke istihdamın yüzde 8'ini istihdam etmektedir. Bu bağlamda, turizm sektöründe ülkeye rekabet avantajı sağlayan temel belirleyicilerin tespit edilmesi ve bu avantajların turizm sektöründe sürdürülebilir bir rekabet gücünün kazandırılmasına yönelik doğru ve yerinde uygulanabilir programlarla desteklenmelidir.

Türkiye'nincoğrafikonumundankaynaklısahipolduğuiklimşartlarıturizm endüstrisi için başlıca temel faktör avantajlarının başında gelmektedir. Ülkenin uluslararası turizm sektöründeki ana rekabet avantajları sahip olduğu temel faktör koşullarından gelmektedir. Ilıman Akdeniz iklimi, Ege ve Akdeniz kıyılarına olan uzun sahil kıyıları, kültürel zenginlikler ve birbirinden farklı turizm rekreasyonel kaynaklarına elverişli akarsu, göl ve kış sporlarına uygun dağlık bölgeleri Türkiye'nin sürdürebilir rekabet avantajı yaratmaktadır. Türk turizm sektörüne rekabet gücüne pozitif yönde etki eden diğer temel koşullar; iletişim sistemlerindeki ilerlemeler, nitelikli iş gücü, doğal kaynaklar, modern ulaşım ve altyapı kaynakları ve üniversite ve araștırma kurumlarıdır. Kültürel mirasların korunma ve yönetimimdeki aksaklıklar, bilgi teknolojileri yazılım programlarındaki dışa bağımlılık, sahil kıyılarından uzak olan turizm noktalarındaki ulaşım altyapısındaki sıkıntılar ülkenin turizm sektörünün rekabet gücüne negatif etki etmektedir. Ayrıca, ülkenin bulunduğu konum itibariyle çevresinin düşük gelirli ülkelerle çevrilmiş olması ve bu ülkelerdeki siyasi ve ekonomik krizler ile savaş gibi faktörlerin yoğun olmasından kaynaklı ülkenin turizm sektörünün rekabet gücünü olumsuz etkileyebilmektedir.

Türkiye'deki iç talep koşulları yapısı bakımından turizm sektörüne olumlu katkı sunmaktadır. Yoğun iç talep yapısının yerel pazarda ki talepkar yapısı sektörde faaliyet gösteren işletmelerin sürekli bir gelişim göstermelerini sağlamaktadır. Ülke 'deki turizm sektörüne yönelik iç talebin yüksek olması uluslararası piyasada ülke turizminin rekabet gücünü pozitif 
yönde etkilemektedir. Turizme yönelik iç talebin, yabancı turistlerin yoğun talepte bulunduğu yaz aylarında olması ayrıca güç sağlamaktadır. Ülkenin turizm endüstrisine yönelik iç talebin yoğunluğunun nitelik yönünden aynı derecede talepkar olmamaları rekabet gücüne olumsuz etki etmektedir. Benzer şekilde, ülkedeki iç talep yapısının kültürel zenginliklerini yansitma yerine uluslararası taleplerin tercih edilmesi sektörünün rekabet gücüne negatif etki etmektedir.

Türk turizm sektörünün sahip olduğu yiyecek ve içecek sektörünün uluslararası rekabet gücü turizm endüstrisine avantajlı hale getirtmiştir. Tedarikçi konumunda bulunan firmaların gelişmiş̧lik seviyesi, bağlantılı sektörlerin desteği, fiyat efektif girdilere hızlı erişim düzeyinin yüksek olması ve ilgili ve destekleyici kuruluşların varlığı ülkenin turizm sektörünün rekabetçi bir yapıda olduğunun göstergesi olarak tespit edilmiştir. Turizm işletmelerin tedarikçi konumunda bulunan inşaat, mobilya, gıda üretimi, tekstil ve iletişim sektörlerin sayıca çok olması ve turizm kümelenmelerin olduğu lokasyonlara yakınlığl, turizm işletmelerine maliyet avantajı sağlamaktadır.

Ülke turizm endüstrisindeki işletmelerin çoğunluğunun kümelenmelerin olduğu lokasyonlarda faaliyet gösteriyor olması firmaların devamlı rekabet içinde olmalarına neden olmaktadır. Sektördeki işletmelerin sürekli bir rekabet yapısı içinde bulunmaları ülkenin turizm sektörüne olumlu lanse edilmektedir, çünkü yerel rekabetin yüksek olduğu piyasalarda, yerel firmaların uluslararası piyasada rekabet şansını artırmaktadır. Türk turizmin sürekli rekabetçi yapısı uluslararası rekabet edilebilirliğine güç katmaktadır. Aynı şekilde, ülkedeki turizm işletmelerinin, uluslararası piyasada bilinirliği olan veya lider konumunda olan zincir otellerle markalaşma yoluna gitmekte veya kendi yerli markasını yaratma yolunda ilerlemeleri turizm sektörüne pozitif etki etmektedir.

Devletin turizm sektörüne yönelik yatırım ve faaliyet teşvikleri, endüstriyi olumlu yönde etkilemiştir. Ulaşım ve altyapıya yönelik yatırımların devam etmesi ve ülkenin turizm kümelenmeleri olan lokasyonlara yönelik güvenlik tedbirleri turizm sektörünü olumlu yönde etkilemektedir. Ancak, kırılgan bir yapıya sahip turizm endüstrisinin, ülkenin bulunduğu coğrafik şartların olumsuzluklar yüzünden ve sık yaşanan terör olayları ve ülkeler arası ilişkilerden doğan anlaşmazlıklar sektörü olumsuz yönde etkilemektedir.

Türk turizm endüstrisinin gelişmesinin başlıca sebebi ülkenin sahip olduğu temel faktör koşullarıdır. Talep koşulları, ilgili ve destekleyici 
endüstriler, işletmelerin kurumsal yapı ve stratejileri, kümelenme, devlet destekleri ve şans faktörleri de ülke turizm endüstrisinin rekabet gücünün gelişmesinde rol oynamıştır. Elmas modeline göre, bazı faktörlerinde zayıf yanların olması ile birlikte, Türkiye'nin turizm alanında uluslararası ölçekte rekabet gücüne sahip olduğunu göstermektedir. Türkiye sahip olduğu temel faktör koşullarının verimli ve etkili bir biçimde kullanması halinde uluslararası dünya turizm endüstrisini en rekabetçi ülkesi haline gelecektir. Ülkenin bulunduğu konum, sahip olduğu kültürel zenginlik ve güzellikler, doğal kaynaklar, hem deniz hem de kıș turizmine elverişli olması gibi temel faktörlerin, nitelikli iş gücü, gelişmiş ulaşım ve altyapı, bilgi teknolojileri gibi ürünlerin verimli ve etkin kullanılması ile tamamlanabilmesi Türkiye'nin rekabet gücünü maksimum düzeyde artıracaktır.

\section{Kaynakça / References}

Arslan, İ. K. ve Şahin. Ş. (2016). Kümelenmenin Kobi'lerin İhracat Performasına Etkisi: Kuyumcukent'te Bir Uygulama. Dış Ticaret Enstitüsü Working Paper Series.

Bulu, M., Eraslan, İ.H. ve Kaya, H. (2006). Türk elektronik sektörünün rekabetçilik analizi. İstanbul Ticaret Üniversitesi Sosyal Bilimler Dergisi, 5(9), 49-66.

Van Den Bosch, F. A. and Van Prooijen, A. A. (1992). European management: an emerging competitive advantage of European nations. European Management Journal, 10(4), 445-448.

Dilber, İ. (2007). Turizm Sektörünün Türkiye ekonomisi üzerindeki etkisinin girdi-çıktı tablosu yardımıyla değerlendirilmesi. Yönetim ve Ekonomi Dergisi, 14(2), 205-220.

Esen, S. and Uyar, H. (2012). Examining the competitive structure of Turkish tourism industry in comparison with diamond model. Procedia-Social and Behavioral Sciences, 62, 620-627.

Gökmenoğlu, S. M., Akal, M. ve Altunışık, R. (2012). Ulusal rekabet gücünü belirleyen faktörler üzerine değerlendirmeler. Competition Journal/Rekabet Dergisi, 13(4), 3-44.

Murat, K. O. C. ve Ozbozkurt, O. B. (2014). Ulusların rekabet üstünlüğü ve elmas modeli üzerine bir değerlendirme. İşletme ve İktisat Çalışmaları Dergisi, 2(3), 85-91.

Konsolas, I. (2002). The Competitive Advantage of Greece : An Application of Porter's Diamond, Aldershot [u.a.] : Ashgate. 
Öz, Ö. (1999). The comparative advantage of nations-the case of Turkey, assessing Porter's framework for national advantage. Aldershot [ua]: Ashgate.

Özer, K. O., Latif, H., Sarıșık, M. and Ergün, Ö. (2012). International competitive advantage of Turkish tourism industry: a comperative analyse of Turkey and Spain by using the diamond model of M. Porter. Procedia-Social and Behavioral Sciences, 58, 1064-1076.

Özer, K.O. (2012). Türk turizm endüstrisinin uluslararası rekabet gücünün değerlendirilmesi: elmas modeli ile Türkiye İspanya karşılaştırması (Yayınlanmamış Doktora Tezi, Sakarya Üniversitesi, Sosyal Bilimler Enstitüsü, Turizm işletmeciliği Anabilim Dalı, Sakarya)

Smit, A. J. (2010). The competitive advantage of nations: is Porter's diamond framework a new theory that explains the international competitiveness of countries?. Southern African Business Review, 14(1), 105-130.

Stopford, J. M., Strange, S. and Henley, J. S. (1991). Rival states, rival firms: Competition for world market shares (Vol. 18). UK: Cambridge University Press.

Porter, M. E. (1998). Competitive advantage of nations: Creating and sustaining superior performance (Vol. 2). Simon and Schuster.

Uzunkaya, M. (2013). Uluslararası Rekabet Edebilirlik Çerçevesinde Türk İnşaat Sektörünün Yapısal Analizi, TC Kalkınma Bankası.

T.C. Ulaştırma Bakanlığı

T.C. Kültür ve Turizm Bakanlığı

UNESCO (Birleşmiş Milletler Eğitim, Bilim ve Kültür Örgütü)

WTTC (Dünya Turizm ve Seyahat Konseyi)

TÜIKK (Türkiye İstatistik Kurumu Başkanlığı)

TURSAB (Türkiye Seyahat Acentaları Birliği)

UNWTO (Dünya Turizm Örgütü)

\section{Summary}

Turkey is among the top 10 destinations in the world tourism industry. Tourism industry provides very important positive contributions to the country's economy. In 2017, 3.1 percent of the GDP of the Turkish economy 
constituted from the tourism industry. The tourism industry supports country's foreign trade deficit by bringing in foreign exchange inflows and employs 8 percent of the country's employment. In this context, it is necessary to identify the basic determinants of the competitiveness of the country in the tourism industry and to support these advantages with the correct and on the spot practical programs aimed at promoting sustainable competitiveness in the tourism sector.

The climate conditions of Turkey originating from its geographical location are one of the main factor advantages for the tourism industry. The main competitive advantages of the country in the international tourism sector come from the basic factor conditions. The Mediterranean climate, the long coastline on the Aegean and Mediterranean coasts, the cultural wealth and the mountainous regions suitable for the lakes and winter sports are creating a competitive advantage for Turkey. Other basic conditions affecting competitiveness in the Turkish tourism sector are developments in communication systems, qualified workforce, natural resources, modern transportation and infrastructure resources and university and research institutions. Problems in the protection and management of cultural heritage, dependence on information technologies software programmes, difficulties in the transportation infrastructure in tourism destinations away from the coast have a negative impact on the competitiveness of the country's tourism sector. In addition, due to its location, its environment is surrounded by low-income countries and its political and economic crisis in these countries and factors such as war can adversely affect the competitiveness of the country's tourism sector.

It contributes positively to the tourism industry in terms of the structure of domestic demand conditions in Turkey. The demand structure of the intensive domestic demand structure in the local market enables enterprises operating in the sector to develop continuously. The high domestic demand for tourism sector in the country has a positive impact on the competitiveness of the country tourism in the international market. Domestic demand for tourism is also strong in the summer when foreign tourists make intense demands. The fact that the domestic demand intensity of the country's tourism industry is not equally demanding in terms of quality has a negative impact on competitiveness. Similarly, the choice of international demands rather than reflecting the cultural wealth of domestic demand structure in the country has a negative impact on the competitiveness of the sector.

The fact that the majority of the enterprises in the country tourism 
industry operate in places where clusters are located causes companies to be constantly competitive. The fact that enterprises in the sector have a continuous competitive structure is positively launched in the tourism sector of the country, because in the markets where local competition is high, the chances of local firms competing in the international market increase. The continuous competitive structure of Turkish tourism adds strength to international competitiveness. In the same way, tourism enterprises in the country, which are known in the international market or the leading position in the chain hotels go to the path of branding or their progress towards creating their own local brand has a positive impact on the tourism sector.

The government's investment and activity incentives for the tourism sector have positively affected the industry. The continued investments in transportation and infrastructure and the security measures for the tourism clusters of the country have a positive impact on the tourism sector. However, the tourism industry with a fragile structure, the geographical conditions of the country due to the negative and frequent terrorist incidents and conflicts arising from relations between countries adversely affect the sector.

The main reason for the development of the Turkish tourism industry is the basic factor that the country has. Demand conditions, related and supporting industries, enterprise structure and strategies of enterprises, clustering, government support and factors of Chance played a role in the development of competitiveness of the country tourism industry. According to the diamond model, Turkey has an international competitiveness in the field of tourism, with weaknesses in some factors. Turkey will become the most competitive country in the international world tourism industry if it uses the basic factor conditions efficiently and effectively. The country's location, its cultural wealth and beauty, natural resources, the basic factors such as being suitable for both sea and winter tourism, qualified labor force, advanced transportation and infrastructure, information technologies, such as products efficiently and effectively will increase the competitiveness of Turkey at the maximum level. 